\title{
Saving the Curriculum or Saving Life? The Risk of Opening Schools in South Africa at the Peak of the Country's COVID-19 Pandemic
}

\author{
Rifumuni Nancy Mathebula \\ Department of Foundations of Education, \\ School of Education, University of Venda, South Africa \\ Tawanda Runhare \\ Department of Foundations of Education, \\ School of Education, University of Venda, South Africa
}

DOI: https://doi.org/10.36941/jesr-2021-0062

\begin{abstract}
Despite stringent preventative measures, the corona virus disease of 2019 (COVID-19) pandemic had adversely affected the contemporary global community. The pandemic has had an inevitable negative impact on education globally. This paper critiques the South African Department of Basic Education's opening of schools at the beginning of severe winter in June 2020 based on the claim of having the capacity to implement preventive measures against the spread of COVID-19 in schools. Using literature, government statements and constitutional frameworks, we argue that it was unrealistic, irrational and contradictory to open schools when the government was decongesting other public sectors and at a time when the country was in severe cold season, which is suitable for the survival of the corona virus. We note that schools opened when the COVID-19 infections and fatalities were heightening in the country, when winter was at its doorsteps and personal protective equipments (PPEs) were inadequately supplied in schools. We also argue that it was a myth that children are safe from COVID-19 and saving the school calendar at the expense of human life was catastrophic and therefore schools should not have opened in the severe winter, without a cure or vaccine for the COVID-19.
\end{abstract}

Keywords: COVID-19, pandemic, coronavirus, infection, lockdown, influenza

\section{Introduction}

On 11 of March 2020, the World Health Organization (WHO) declared the coronavirus disease of 2019 (COVID -19) outbreak a global pandemic (Motala \& Menon, 2020; Mahaye, 2020). The coronavirus first emerged in the Chinese province of Wuhan in December 2019; hence it's known as COVID -19 and is the seventh known worldwide virus that has attached humanity. Others before were Swine flu ( $\left.\mathrm{H}_{1} \mathrm{~N}_{1}\right)$ (2009-2010), Hong Kong flu (1968-1969), Asian flu (H2N2) (1957-1958), Spanish flu (1918-1919), Six cholera pandemic (1899-1920) and The Black Death (1346-1350) (Felman, 2020). Literature indicates that approximately a billion people are still under lockdown after their lives were forcefully brought to a virtual cessation by the rapid spread of COVID-19 (Caduff, 2020; Ramrathan, 2020). Previous studies reveal that the coronavirus family causes various infectious sicknesses ranging from the common cold to more extreme virus-related illnesses such as severe acute respiratory syndrome (SARS) (Cirrincione et al., 2020; Kanyinda, 2020). Its speedy spread worldwide is also attributed to globalisation as people 
travel widely and very fast through air flights for business transactions that can result in a person landing on many countries within a day. Consequently, China, the emerged economic giant of this century has been blamed by United States of America for spreading the mysteriously dangerous virous, whose exact origin is still obscure.

In January 2020, WHO declared that SARS-CoV-2 was a causal agent of COVID-19 (Guo et al., 2020; Khan, 2020). Many COVID-19 patients, first identified in China were hawkers at a poultry, seafood as well as live wildlife market. Although the first positive viral cases were transmissions from an animal source, currently the virus spread is from one person to another (Andersen et al, 2020). Like influenza and other respiratory pathogens spread, COVID-19 also spread mostly through respiratory droplets produced when an infected person coughs or sneezes (Cirrincione et al., 2020; Shereen et al, 2020, 2020). COVID-19 patients have common symptoms which include mild to extreme respiratory disease with sore throat, cough, fever, breathing difficulties or shortness of breath whereas in life-threatening cases, the virus can cause numerous organ failure, pneumonia and death (Huang et al. , 2020).

The incubation period of COVID-19 is one to fourteen days; however, the virus is transmissible before symptoms appear, and many people get infected within a short span of time (Jin et al., 2020). Studies show that some infected patients are asymptomatic, meaning they do not show any viral signs although having the virus in their body systems (Bai et al., 2020; Mahaye, 2020). Medical treatment of severely ill patients is mainly supportive by providing oxygen for patients with breathing difficulties or treating a fever as COVID-19 has no known cure yet. By June 2020 when almost every country in the world was getting infected by COVID-19, there was no specific antiviral treatment available world-wide (Khan, 2020).

With regards to South Africa, on 05 March 2020, the National Institute for Communicable Diseases (NICD) confirmed that the first COVID-19 patient was a 38-year-old male who travelled to Italy and arrived back in South Africa on o1 March 2020 (Wiysonge, 2020). The patient consulted a doctor on 03 March with coronavirus-related symptoms and his blood tested positive to COVID -19, leading to panic in the country.

From 27 March 2020, South Africa was compelled into national lockdown when all business and public institutions were closed and people instructed to stay indoors except for very exceptional needs like going for medical assistance (Schleicher, 2020; Van der Berg \& Spaull, 2020). Primary and secondary schools were the first to be closed on 18 March 2020 due to the fear that young children, who cannot comprehend safety and prevention measures were in danger and most vulnerable. After two months and as the infection numbers grew from 100 to over 30 ooo by June 2020 , South Africans became highly divided on why the government decided to open primary schools even before universities could open. The question which ignited this paper is why government sent a contradictory message by hurriedly closing basic education system in fear of COVID-19 and then opened the same schools first, putting the young children in the same vulnerability that caused sudden closure of schools. We therefore argue that it was catastrophic to open schools before a clear understanding of the behaviour of COVID-19 and the prevention measures were tried and tested.

\section{The Advent of COVID-19 on the Global Landscape}

Available literature indicate that COVID-19 pandemic is not the first deadliest virus which adversely affected people around the world, it subsequent the Spanish flu which outbroke in early 1918 during the fifth year of the World War I (Ramrathan, 2020; Tornali, Vecchio \&Vecchio, 2020). The Spanish Flu virus originated from American states and rapidly prevailed to all European countries and only publicised when it reached Spain hence its spurious name is "The Spanish flu" (Parle, 2019, p.293). The Spanish flu is also known as the 'great' or 'Spanish' influenza epidemic of 1918 - 1919. It was mostly transmitted from America to Europe by the American troops” (Parle, 2019, p.293). The said literature reveals that the progenitor of the recent influenza A-sub type $\mathrm{H}_{1} \mathrm{~N}_{1}$ virus is the Spanish influenza virus ((Tsoucalas, Kousoulis and Sgantzos, 2016). The virus visited the region in three waves from March 1918 to August 1919 and it was killing many people around the world more than the First World War. 
However, compared to COVID-19 when the world is now a global village as a person can have breakfast in Pretoria and supper in London, the spread of the Spanish flu was not so magnanimous.

After the official pronouncing of COVID-19 outbreak on 11 March 2020 by WHO, the prevalence of the virus was recorded and published world-wide. International statistics revealed that since 31 December 2019 and as of 27 May 2020, COVID-19 reported cases were 5555737 and confirmed death cases were 350212 across the world. By March 2020, China where the virus originated had 84103 confirmed cases and 4638 deaths (European Centre for Disease Prevention and Control, 2020). Table 1 presents data from top five worst-hit African countries. In Africa, there were 67638 cases confirmed and 2389 deaths cases across the continent by end of May 2020.

Table 1. Prevalence of COVID-19 of five African countries

\begin{tabular}{|l|c|c|}
\hline Country & Confirmed Cases & Confirmed Deaths \\
\hline South Africa & $\mathbf{2 4 2 6 4}$ & 524 \\
\hline Egypt & $\mathbf{1 8 7 5 6}$ & 797 \\
\hline Algeria & 8697 & 617 \\
\hline Nigeria & 8344 & $\mathbf{2 4 9}$ \\
\hline Morocco & 7577 & $\mathbf{2 0 2}$ \\
\hline Total & $\mathbf{6 7 6 3 8}$ & $\mathbf{2 3 8 9}$ \\
\hline
\end{tabular}

Source: Africanews, 27 May 2020, pp. 1-2

Table 1 presents the five hard-hit African countries having more than 7000 thousand confirmed cases and 200 deaths by 27 May 2020, which was only three months after the virus was first identified in South Africa (Shaban, 2020). South Africa was the most affected country followed by Egypt, though Egypt and Algeria were having more fatalities from the virus than South Africa. What is of interest to our argument is that Egypt, which trailed South Africa in terms of infection rate declared that their schools closed. Egypt reopened its schools on 17 October 2020 (Xinhua, 2020). After the pandemic reached the continent, African countries followed by imposing a range of prevention and containment measures against the spread of the pandemic hence they have low infections. At the same time, United Nations International Children's Emergency Fund (UNICEF) South Africa COVID-19 Situation Report No. 7 of August 2020 indicated that, "South Africa continues to have the highest number of COVID-19 cases in Africa, with a total of 628,259 confirmed infections, 550,000 recoveries and deaths is 14,236 " (UNICEF, 202ob, p.1).

Table 2 is summary of ten selected Southern African Development Community (SADC) in the early period after COVID -19 was declared a global disaster.

Table 2. Prevalence of COVID-19 of ten SADC

\begin{tabular}{|l|c|c|}
\hline Country & Confirmed Cases & Confirmed Death \\
\hline South Africa & $\mathbf{2 4 2 6 4}$ & 524 \\
\hline Zambia & 920 & 07 \\
\hline Tanzania & 509 & 21 \\
\hline Mauritius & 334 & 10 \\
\hline Mozambique & 213 & 01 \\
\hline Malawi & 101 & 04 \\
\hline Zimbabwe & 56 & 04 \\
\hline Botswana & 35 & o1 \\
\hline Namibia & $\mathbf{2 1}$ & oo \\
\hline Lesotho & $\mathbf{0 2}$ & oo \\
\hline Total & $\mathbf{2 6} \mathbf{4 5 5}$ & $\mathbf{5 7 2}$ \\
\hline
\end{tabular}

Source: COVID-19 Situation Update World-wide: European Centre for Disease Prevention and Control, 27 May 2020, pp.1-12. 
It is evident that by May 2020, South Africa had highest number of confirmed COVID-19 cases as compared to other SADC members. The major contributing factor is that South Africa is the international hub between Africa and Europe, and it is a known fact that the virus most likely reached Africa via Johannesburg, Cape Town and Durban where there are direct flights from Europe, China and America. In fact, South Africa's population of infection is higher than all the other SADC countries combined, yet none of them had not yet opened their schools by June 2020, which is the peak of SADC winter season.

Table 3 presents death cases of COVID-19 by age in South Africa as announced by Health Minister from 27 May to 31 May 2020.

Table 3. Death cases of COVID-19 in South Africa by age.

\begin{tabular}{|c|c|c|c|}
\hline Age & 29 May 2020 & 30 May 2020 & 31 May 2020 \\
\hline 0-9 & $\mathbf{2}$ & $\mathbf{2}$ & $\mathbf{2}$ \\
\hline $10-19$ & 1 & 2 & 4 \\
\hline $20-29$ & 4 & 39 & 40 \\
\hline $30-39$ & 34 & 70 & 77 \\
\hline $40-49$ & 68 & 160 & 174 \\
\hline $50-59$ & 152 & 169 & 176 \\
\hline $60-69$ & 162 & 124 & 133 \\
\hline $70-79$ & 120 & 59 & 60 \\
\hline $80-89$ & 57 & 14 & $\mathbf{1 5}$ \\
\hline $90-99$ & $\mathbf{1 1}$ & $\mathbf{6 4 3}$ & $\mathbf{6 8 3}$ \\
\hline Total & $\mathbf{6 1 1}$ & & \\
\hline
\end{tabular}

Source: Department of Health, South Africa, 29 May 2020 to 31 May 2020, pp. 1-6

One of the early day's myths of COVID-19 was that it is a disease for white people only and that it does not infect and affect young people and children at all. From the above table, it might seem logical for the South African Department of Basic Education (DBE) to have opened schools in June as only four people below 20 had died from COVID-19. However, the four fatalities were not less important human lives and so the problem should not be superficially viewed that children were not at risk.

On 16 March 2020, just two weeks after the first South African COVID-19 patient was diagnosed, it was reported that a Grade $\mathrm{R}$ learner in the northern KwaZulu-Natal had tested positive to COVID19. The case was confirmed by provincial Member of Executive Council (MEC) of Education who indicated that "We can confirm that one Grade R learner from Richards Bay Primary tested positive" (Singh, 2020, p.1). In June 2020, it was further reported that 37 children had tested positive to COVID19 since the start of the pandemic (Jacobs, 2020), which dispelled the myth that children do not get infected by the corona virus (Ndebele, 2020). It is based on such realities that we argue against opening of schools when South Africa was getting into the winter season, which is the safe habitat season for the virus.

Meanwhile, as indicated in the table below, the COVID -19 infections and fatalities continued to rapidly increase.

Table 4. Prevalence of COVID-19 in South Africa by province by 31 May 2020

\begin{tabular}{|l|c|c|c|c|c|c|}
\hline & \multicolumn{3}{|c|}{ Confirmed Cases } & \multicolumn{3}{c|}{ Confirmed Death } \\
\hline Province & 29 May 2020 & $\mathbf{3 0}$ May 2020 & $\mathbf{3 1}$ May 2020 & 29 May 2020 & 30 May 2020 & $\mathbf{3 1}$ May 2020 \\
\hline Western Cape & $\mathbf{1 8 9 0 6}$ & $\mathbf{2 0 1 6 0}$ & $\mathbf{2 1 3 8 2}$ & 437 & 465 & 503 \\
\hline Gauteng & 3585 & 3773 & 4003 & 31 & 31 & 33 \\
\hline Eastern Cape & 3583 & 3759 & 3927 & 80 & 82 & 82 \\
\hline KwaZulu-Natal & $\mathbf{2 4 2 8}$ & $\mathbf{2 4 7 6}$ & $\mathbf{2 5 4 5}$ & 50 & 52 & 52 \\
\hline
\end{tabular}




\begin{tabular}{|l|c|c|c|c|c|c|}
\hline & \multicolumn{3}{|c|}{ Confirmed Cases } & \multicolumn{3}{c|}{ Confirmed Death } \\
\hline Province & 29 May 2020 & $\mathbf{3 0}$ May 2020 & 31 May 2020 & 29 May 2020 & 30 May 2020 & 31 May 2020 \\
\hline Free State & 231 & 261 & 278 & 8 & 8 & 8 \\
\hline Limpopo & 170 & 173 & 177 & 3 & 3 & 3 \\
\hline North West & 143 & 162 & 175 & 1 & 1 & 1 \\
\hline Mpumalanga & 112 & 113 & 121 & 0 & 0 & 0 \\
\hline Northern Cape & 52 & 57 & 69 & 1 & 1 & 1 \\
\hline Unknown & & 33 & 06 & & & $\mathbf{6 1 1}$ \\
\hline Total & $\mathbf{2 9 2 4 0}$ & $\mathbf{3 0 9 6 7}$ & $\mathbf{3 2 6 8 3}$ & $\mathbf{6 1 1}$ & $\mathbf{6 8 3}$ \\
\hline
\end{tabular}

Source: Adapted from Department of Health, South Africa, 29 May 2020 to 31 May 2020

At the time of writing this paper, it was a few days before the scheduled re-opening of schools on o1 June 2020 and we present the prevalence of COVID-19 on the very last day of May 2020 in Table 4, which shows an alarming increase of the virus infections (Department of Health, 2020d, 2020e, 2020f). On 27 March 2020 when the national lockdown was commenced, there were 1170 cases and 02 fatalities out of 28537 tests conducted but at the eve of school opening, there were 32683 cases and 683 fatalities out of 725125 tests conducted (Department of Health, 2020f). It therefore did not make logic at the time why the South African government got the courage to expose children and to ignore the danger of the coronavirus during the cold winter and amid the fact increasing infections of the virus.

On 19 May, when the DBE minister announced the official opening of school on o1 June 2020, it was widely opposed throughout the country. The province which had the highest virulent cases was Western Cape, which was confirmed as the epicentre, followed by Gauteng then Eastern Cape and the fourth hard-hit is KwaZulu-Natal. Although Gauteng had more confirmed cases than Eastern Cape, Gauteng had less deaths than Eastern Cape. Surprisingly, was the Western Cape which first opened its schools on the o1 June 2020 against the Minister's postponement of opening of schools to o8 June 2020, which could just be a political gimmick of the main opposition Democratic Alliance (DA) led provincial government to oppose national government pronouncements (Nortier, 2020). Despite the adherence of health protocols, the viral spread heightened rapidly. As of 31 August 2020, a UNICEF report noted that, "Gauteng province has the highest number of cases $(209,648)$, followed by KwaZulu-Natal $(112,726)$ and the Western Cape $(105,908)$. The number of new cases had then increased by over 12,000 every day in July" (UNICEF, 202ob, p.1).

The question that human rights activists had not got adequate answer to be the wisdom of saving the economy and education at the expense of life, which the Roman Catholic Church leader, Pope Francis also warned against (Pullella, 2020). Although some commentators, Masekela and Wessels (2020, p.72) concurred with the DBE that, "Schools should remain open in order for the majority of children in this country to benefit from a safer learning environment, nutrition and mental health", we argue in this paper that a person can only live once but can redress the economy, poverty or educational drawbacks, and therefore life is primary to all other necessities of life. To risk the life of children in search of education could result in national health catastrophe. So, schools should have remained closed until the start of the hot season in August as the COVID-19 virus does not easily survive in high temperatures (Wang et al, 2020).

\section{Uncertainties on COVID-19 Preventative Measures in Schools}

The World Health Organisation (WHO) reported that in response to fight COVID-19, countries around the world implemented several public health and social measures (PHSM), which included movement restrictions, closure of schools and businesses and also international travel restrictions (Van der Berg \& Spaull ,2020; Schleicher, 2020). In South Africa, due to intense rapid viral spread, on 15 March 2020, the president announced three-day earlier closing of schools for term one from 18 March 2020 as a way of averting the spreading of COVID-19. By then, people who tested positive were 51 and there was no 
fatality (Republic of South Africa, 2020a). This was followed by a national lockdown on 27 March 2020, which enforced severe restrictions on travel and any movement, as people were forced to stay indoors. The national lockdown started when South Africa was sitting at 1170 COVID -19 confirmed cases and o2 deaths (Republic of South Africa, 2020b).

The question that we raise in this paper is why schools were opened without testing the confidence level of teachers and learners on all the above requirements. It was also irrational that while gatherings of more than 50 people at funerals and religious worship centres were not allowed in level 3 from o1 June, schools which attracted hundreds of learners, teachers and non-teaching staff were opened. While measures such as fumigation of schools and supply of personal protective equipment (PPE) was mandatory for any school to open its doors, many schools failed to open because of incapacity to secure adequate PPEs for only two grades (Joint Media Statement, 2020).

Regarding school safety, the South African Democratic Teachers Union (SADTU), National Professional Teachers' Organisation of South Africa, (NAPTOSA), National Teachers Union (NATU), Professional Educators Union (PEU) and the South African Onderwysunie (SAOU) presented their stance that the non-negotiable requirements should be met by the Minister of Basic Education before schools should re-open. These requirements include adequate sanitation, observance of social distancing inside the classrooms and on school yards, reduction of class sizes, provision of soap, sanitizers and masks, screening of learners, teachers and support personnel, social distancing in transportation of learners to and from schools and provision of psycho-social services (Molele \& Tefu, 2020; Joint Media Statement, 2020). With such opposition from the teacher controlling unions on unavailability of PPEs, it was unwise for the DBE to demand schools to reopen without winning the absolute support and confidence of teacher unions for they determine the motivation of teachers.

\section{DBE Minister`s Unjustified Reopening Schools}

The United Nations Educational, Scientific and Cultural Organization (UNESCO) reported that most governments' world-wide had temporarily closed educational institutions to combat the spread of the COVID-19 pandemic (Motala \& Menon 2020). On 19 May 2020, South Africa was sitting at 17200 confirmed cases and 312 death cases. Despite the high figures, the DBE minister announced the reopening of schools on the or of June 2020 in phased approach and the first groups were Grade 12 and Grade 7. However when asked on the guarantee of safety of the learners in schools, the minister contradicted herself by informing the nation that, "I cannot guarantee that every single pupil will be safe from contracting Covid-19 when grade $7 \mathrm{~s}$ and 12s go back to school on June 1" (Mvumvu, 2020, p.1). This was like shifting the blame to school authorities should anything go wrong. This blame shift game took another dimension when some schools forced parents to sign indemnity forms in which they absolved schools should their children contract the virus (Phagane, 2020; WCED, 2020), which clearly showed lack of trust in the move to re-open schools by the DBE.

Despite the minister's call to re-open schools and save the school year, teachers' unions discovered that this would cost life because PPEs for both staff and learners were not delivered by then. Most schools were not disinfected, and sanitation and water crisis still prevail in many schools especially those from rural areas (Joint Media Statement, 2020). Although we acknowledged the Right to Education, Section 29 as endorsed in the Constitution of the Republic of South Africa No 108 of 1996 and the South African Schools Act (SASA) No 84 of 1996, the right of children and teachers to life is to us a primary human right to that of education. It is only when one has life and security that the right to education can then be meaningfully pursued.

The whole of Africa is facing a situation of being overstretched by the COVID-19 pandemic in terms of capacity of health institutions, and South Africa is equally affected in this regard. It was therefore catastrophic at the time for South Africa to ignore comparing itself with other African countries with the false belief that it is better equipped and resourced when many schools could not open due to inadequate supply of PPEs (Joint Media Statement, 2020). This paper opposes South Africa's justification of re-opening schools under COVID-19 pandemic with other SADC members, 
African countries and international countries like the also hard-hit Egypt which had indefinitely delayed opening of basic education sector, while Kenya was the first African country to courageously declared that schools will open in 2021 (Rai, 2020).

\section{Unattainable Social Distance Requirements for Schools}

Previous studies show that social distancing is crucial for preventing the spread of COVID-19 because the virus can transmit through coughing, sneezing and close contact (Khan, 2020; Ramrathan, 2020). The said studies further explain that people must maintain social distancing by keeping at least 1.5 meters in between. On 20 May 2020, Basic Education Director-General, announced guidelines to reduce the risk of coronavirus infection in schools. In the same vein, Director-General strongly accentuated the prerequisite of social distancing as the most effective way of combating the prevalence of COVID-19. He recommended limitation of movement of learners in classes, restricting clustering and sharing of desks, observing physical distance of 1, 5 meters and strictly one learner per desk. He outlined the department protocols which strongly limit hugging, handshaking, direct contact, assemblies, and large groups of learners including extra classes (Department of Basic Education, 2020).

The clear concern is that such stringent preventive measures of maintaining social distancing are unrealistic to children and in under-resourced schools where learners shared textbooks. Children by nature like to play together and share, to the extent that the public had already indicated that learners could share their face masks. Take for example Grade R who learn through play, they voluntarily love sharing, pushing, touching, patting, slapping, hugging and put mouth on the tap when they drink water. Their mental level cannot understand the principle of social distancing. Training the Grade $\mathrm{R}$ learners to adhere to social distance rules would take long time. On 18 April, City Press published a statement of the chief executive of SAOU which indicated that social distancing is not easy to implement in schools (Fengu, 2020, p.2). He indicated that, "The most complex issues facing schools would be maintaining social distancing among pupils, particularly a concern with regards to Grades $R$ to 3 where it would be impossible to implement the $1.5 \mathrm{~m}$ social distancing".

With regard to carrying capacity, a normal classroom accommodates 40 learners, if social distance of 1, 5 metres is observed. A normal classroom can carry between 15 and 20 learners depending on the size of the desk. We observed that in most public schools, there is challenge of overcrowding which is caused by various factors including shortage of classrooms, shortage of teachers, shortage of furniture and sometimes institutional factors. Minister of Education reported that a total of 1577 schools were vandalised, and some were burnt with KwaZulu-Natal having 463 and Gauteng 336 respectively (Mvumvu, 2020). We noted that even if mobile classes could be provided, the carrying capacity of mobile class is less than a normal classroom. A mobile classroom can accommodate 10 to 15 learners when observing social distance. Based on the above clarification, we argue that the rule of social distancing in classroom is not achievable in many public schools due to inadequate infrastructure. Van der Berg and Spaull (2020, p.2) also concur that, "The DBE should acknowledge that it is not feasible for most South African schools to practice social distancing within the classroom".

Regarding learner transport, national COVID guidelines stipulate that social distance rule of 1, 5 metres between learners in the buses must be adhered (Department of Education, 2020). We noted that the preventive measure of managing distance between learners in the buses including taxis and bakkies (more especially in townships and villages) which were privately hired by parents, was unrealistic. This observation was reinforced by SADTU Limpopo province who complained that since most scholar transport was not contracted by the department but managed by private service providers would cause a high risk because drivers usually overload learners to make profits (SADTU Limpopo Province, 2020).

\section{Unrealistic Preventive Expectations for Children}

As alluded earlier, the DBE outlined national COVID-19 guidelines on the deterrence of spread of COVID-19 in schools. On 20 May 2020, the department`s director-general called for adhering to social 
distancing rules, compulsory wearing of cloth face masks throughout the school day by both learners and teachers, physical distancing in classrooms observing 1,5 meters and total avoidance of hugging, handshaking and direct contact (Department of Health, 202ob; UNICEF, 2020a). The basic principles to mitigate the viral spread were discussed and this paper reveals that some of the preventive measures expected for children were unrealistic.

Preventive measure seemly challenging to learners is wearing of cloth face masks. With special reference to Grade R learners, who are five years old to wear face cloth masks for over five hours from around 07:00 to12:00 when they started to travel back home. This preventative measure was unrealistic, it needed enough time for the kids to be trained from home which was difficult because the government hastily decided to re-open schools.

One health protocol which was unrealistic for most learners in South Africa was the acknowledgement by the education minister that there were 3500 schools that faced critical water supply challenges country-wide, especially in rural areas (Department of Education, 2020). Teacher unions conducted their own survey of school principals' readiness to reopen schools and found that by 29 May 2020, water tanks which were promised by the department of water and sanitation were not yet delivered to schools (Joint Media Statement, 2020). On this issue, the Congress of South African Students (COSAS) in Limpopo threatened to close all schools in the province because 42 schools had not yet reopened by 25 June 2020 due to lack of readiness (Molefe, 2020). The under-readiness of most rural schools was also revealed by education expert, Professor Jonathan Jansen, who alluded that, "What the virus has done is expose the inequalities in school system because in the majority of schools there isn't bandwidth, there isn't a laptop" (King, 2020, p.1). On the same breath, Arndt et al, (2020) also concur that South African government has not managed to provide all public schools with basic infrastructure like running water, proper sanitation, electricity and safe toilet facilities in the past 25 years of democracy. This exposed the DBE in terms of the existing gap between policy pronouncements and implementation which caused a COVID-19 health catastrophe in schools (Geach, 2020; McLaughlin, 2020).

\section{Realistic Risk of New Wave of COVID-19 Pandemic in Schools}

Following education minister's advice, president Ramaphosa officially declared the re-opening of schools on the o1 June 2020. In his address, he pronounced that there were 22583 confirmed cases and 429 South Africans had lost their lives (Republic of South Africa, 2020a; Department of Health, 2020c). The rise of COVID-19 cases in South Africa was projected by Dr Sheetal Silal, who estimated that there would be 30 ooo confirmed cases and 475 of death cases by end of May with one million cases projected by June and July while 40 ooo deaths were predicted by November (Child, 2020, Davis, 2020; Hunter, 2020). In accord, the president attested that the prevalence of the coronavirus infections would rapidly continue to rise in numbers, and it would get more intense before it subsides.

Based on the said projections, it is evident that reopening of schools while the spread of coronavirus is rising, is a negligent oversight by the government. Meanwhile on 30 April 2020, the Education Minister specified that the health and safety measures affected more than 12 million learners, 407 oo1 educators attached to 23076 schools in the country (Department of Education, 2020). Based on these numbers, it is obvious that education is a big sector, if a learner or staff is infected, the viral spread would be transmitted to thousands of people within a day. SADTU expressed their dissatisfaction regarding the re-opening while the infections were at rife, "Schools are considered highrisk environments because of the number of pupils near one another. We cannot afford to lose lives. Corpses can neither be taught nor teach" (SADTU Media Statement, 2020, p.2). In the same vein, NAPTOSA executive member warned the government. He advised that, "There will be possible infections if a positive pupil attended school. The school may be contaminated and starts another ball game" (Fengu, 2020, p.5).

On the 18 of April 2020, Fengu (2020, p.2) reported a similar statement criticising the Department of Basic Education for re-opening the schools as raised by concerned parent who complained that: 
It was really shocking to hear about department's plan to re-open schools, is not making any sense. Schools must be the last place to open for mass gathering. No minister or union can stop the virus, if something bad happens, they will only apologies. Health is our wealth.

The national president announced the identified 12 coronavirus hotspots which were: Tshwane, Johannesburg, Ekurhuleni, Ethekwini, Nelson Mandela Bay, Buffalo City, Cape Town, West Coast, Overberg and Cape Winelands district municipalities, Chris Hani district in the Eastern Cape, and iLembe district in KwaZulu-Natal (Republic of South Africa, 2020). On 29 May 2020 another two hotspots were also identified; Mangaung metro in the Free State and Oliver Tambo district municipality in the Eastern Cape which resulted in South Africa having14 hotspots (Cowan, 2020). Western Cape was the worst-hit province and it was declared an epicentre which has more than half the total infections and deaths cases in the country, yet the government announced re-opening schools nation-wide including hotspots areas. There is no exception of re-opening schools based on statistics of COVID-19 and we therefore conclude that the decision was taken without considering the safety needs of children and could therefore be viewed as denying their right to safety and health.

Evidence of realistic risks in schools was reported two days before the schools re-open as the prevalence of infections amongst school staff members was confirmed by Western Cape Education MEC who indicated that "There are 32 schools and 37 school staff members who have been affected by Covid-19 in the Western Cape ahead of the schools reopening" (Mlamla, 2020, p.1). In addition, Gauteng provincial MEC for education also confirmed two COVID-19 cases amongst teachers and one principal (Njilo, 2020). From a human and child rights point of view, it was irrational and unjust for school children to be compelled to go to school in large numbers at the heightening period of the pandemic while adults were limited to 50 for funeral and church services.

On o8 May 2020, the president announced the release of 19 ooo prisoners to combat the predominance of viral infections in prisons after some prisoners and staff tested positive (Republic of South Africa, 202ob). As alluded earlier, there were more than 12 million learners in South African schools, yet schools were re-opening while having millions of learners as compared to 19 ooo prisoners who were adults. It was evident that the decision to re-open schools was taken at political level and not at humanitarian grounds. To us, there was no logic of decongesting churches, weddings, funerals and prisons as a mitigation measure against COVID-19 while moving to congest schools.

The risk of spreading the COVID-19 in schools was recorded in some countries like France which recorded new cases of coronavirus a week after re-opening schools. On 18 May 2020, the French minister of education announced that 70 learners were infected although schools were required to adhere to social distancing rules and children wearing masks and face shields (Perper, 2020). Another country which had transmission of the virus in schools was Finland where five new cases of COVID-19 infections were reported in schools only a week after re-opening (Daniels, 2020).

\section{Reality of Resuscitation of Wave of COVID-19 Pandemic in Schools}

Despite the highest number of COVID-19 cases, South Africa reopened schools on o8 June 2020 after the teacher unions disputed the re-opening on the or of June 2020 due to the fact that most schools were not ready across the country, PPEs were not delivered for both teachers, support staff and returning Grade 7 and Grade 12 learners (Joint Media Statement, 2020). Few days after reopening of schools, the reality of viral spread in schools was consistent to our argument of realistic risks of reopening school amidst COVID-19 pandemic. Although health protocols were strictly adhered to and schools were disinfected, on 15 June 2020, seven days after re-opening of schools, Anadolu Agency released a shocking report. It was revealed that 98 teachers and 1,80o learners had tested positive COVID-19 in South African schools (Kavak, 2020). However, the basic education defended that revelation by indicating that those was not school infections, but it was community infections because both learners and teachers were infected before schools were reopened. Gauteng education MEC was quoted, "Since the re-opening of schools, there's no direct learner or single teacher that got the virus 
from our school premises and that's a fact. All the people that tested positive are because our systems picked them up before them even arrived within the school premises" (Makhubele, 2020, p.2).

We argue that schools should have not been reopened before vaccine or specific antiviral treatment is available and the effectiveness of prevention measures are proven because at this stage, basically no one including scientists is acquainted with how calamitous the coronavirus is. To us, reopening of schools gives the impression that the DBE is ironically opening centres for gathering people to quickly spread the coronavirus hence positive learners surpassed 1500 (Kavak, 2020). Although other studies by Masekela and Wessels (2020) show that children are much less likely to acquire COVID-19 than adults, we cannot ignore that children can be asymptomatic (Bai et al., 2020; Mahaye, 2020). This is a clear indication that children, though with high recovery rate, can get infection and they can carry the virus from home to school and from school to their families.

Some media reports revealed an emergent trend in the prevalence of positive cases and fatalities of staff members due to coronavirus in schools. On the 15 of June 2020, seven days after reopening schools, South Africa was sitting at 70,038 confirmed cases and 1,480 fatalities including deaths of teachers across the country (Department of Health, 2020c). Press reports indicated that between o8 June and 15 June 2020 quite number of South African schools were closed due to infected learners, teachers and support staff (Evans, 2020; Kgosana, 2020; Nair, 2020; Nyoni, 2020; Zulu, 2020). On 19 June 2020, the Star News reported that in Western Cape province, which was the coronavirus epicentre, a total number of 160 schools were closed while Eastern Cape had 30, Gauteng had 52, KwaZulu- Natal had 28 and North West had 12 schools which were also closed (Mahamba, 2020).

As alluded to earlier, one UNICEF report showed that the number of new cases increased above 12,000 daily in July (UNICEF, 2020b, p.1). On o1 July 2020, the NICD Report noted that, "There was 230 children in South Africa admitted with Covid-19, 16 were admitted into Intensive Care Unit and six were ventilated at some point during admission. Three children aged between o-9 have died from the virus" (Rall, 2020, p.2). On the same note, on 04 July 2020, WCED spokesperson was quoted, "Nineteen school staff died of Covid-19 in the province. No pupils' deaths had been reported" (Geach, 2020, p.1-2) meanwhile on 22 July 2020, the Education MEC revealed that, "379 pupils have tested positive for Covid-19 in the province since June 1, when the first grades returned to classes" (Tswanya, 2020, p.1). Whereas Gauteng education MEC was cited, "A total of 519 teachers and 151 learners have also tested positive for COVID-19 (Molele, 2020, p.1). On the other hand, Kwa Zulu-Natal premier asserted that, "139 teachers and 37 pupils in KwaZulu-Natal have been infected with Covid-19" (Rall, 2020). Meanwhile Sunday World also reported that there were 204 learners and hostel assistants who tested positive for COVID-19 at an Eastern Cape secondary school (Khumalo, 2020). All these press reports were clear indications that the reopening of schools brought a new wave of infections from schools.

In consistent with our argument which predicted the risk of reopening schools amid COVID-19 pandemic, the Public Servants Association (PSA) also advised the education minister to retract the decision to reopen schools were closing daily due to the increase of virus infection cases was becoming the norm in schools as well as the country at large, which was disruptive to academic progress, for which schools were reopened (Mahamba, 2020). Sharing the same sentiment, COSAS strongly called the DBE to close schools in Gauteng and Western Cape provinces due to high rate of COVID-19 confirmed cases in schools (Kgosana, 2020). Despite the concerns raised by various stakeholders, schools continued to operate amid COVID-19 pandemic, although UNICEF concerned that, "school attendance in all provinces is at a worrying low of $75 \%$ or below" (UNICEF, 202ob, p.1).

Our argument is that schools should have not reopened when the viral infections were increasing at the very peak of the corona virus infection in South Africa and without availability of a cure or a WHO approved vaccine (Cirrincione et al., 2020; Kanyinda, 2020). We viewed the reopening of schools at the time as unstrategic because the DBE was warned by various education stakeholders such as teacher unions, school governing body associations, political parties, education experts and the South African Human Rights Commission (SAHRC). We noted that the escalating death toll had psychological effect on children so to reopen schools was depressing, discomforting, demoralising as well as demotivating to teachers, learners and parents (Geach, 2020). This is supported by the 
observation that, "Pandemic fear is unnerving and mentally exhausting" (Caduff, 2020, p.15). We concluded that South Africa was playing as the heroine African country by reopening schools amidst COVID-19, yet it was the fifth highest worst-hit in the world at the time (Fleming, 2020; Magome, 2020).

\section{Conclusion}

This paper concludes that it was an unrealistic consideration to reopen schools during lockdown level 3 in South Africa as it violated the constitutional rights of learners, educators and support staff to health and safety during the peak of the coronavirus infections in the country (Republic of South Africa, 1996a). The education system was incompetence in containing the spread of virus prior re-opening schools due to inadequate provision of necessities such as PPEs, clean water, teaching and cleaning staff (Joint Media Statement, 2020).

According to the South African Constitution, Bill of Rights Section 10 of Act No.108 of 1996, schools, as the custodians of children's fundamental rights, should guard against the violation of basic human rights such as the right to human dignity, which entails that everyone has inherent dignity who deserve to be respected and protected from any types of threats to life, as it is evident that COVID-19 was life threatening. The right to safe environment which according to Section 24 of the constitution extends the right for all citizens to environments which are not harmful to their well-being and health. We argue that under the coronavirus pandemic from March to August 2020, schools could be regarded as a threat to personal health because of their infrastructural, resource and personnel unpreparedness to deal with prevention of virus infections. South Africa, as a UN member state ratified the Convention on the Rights of the Child (CRC) of 1989 which mandate member states to safe-guarding children rights and to take all appropriate measures to ensure that the child is protected against all forms of violation of their rights (UNCRC, 1989). Further, the South African Children's Act states that "In all matters concerning the care, protection and well-being of a child the standard that the child's best interest is of paramount importance, must be applied" (Children Act, 2005, p.34)

Instead of trying to save the curriculum in vein, South Africa might have risked failing to save both the curriculum and life. We therefore recommend that schools should have remained closed or the DBE should have opened only the Grade 12 and 7 learners could be allowed to complete their high and primary school respectively, in order to give room for progression in 2021. With Grade 12 class of 2020 going out of the system, all other grades can be progressed into the next grade to allay the fear that the 2021 school calendar would be disrupted.

\section{References}

Andersen, K.G., Rambaut, A., Lipkin, W.I., Holmes, E.C. \& Garry, R.F. (2020). The proximal origin of SARS-CoV2.Nature Medicine, 26, 450-52.[Online]Available: Doi:10.1038/s41591-020-0820-9.

Arndt, C., Davies, R., Gabriel, S., Harris, L., Makrelov, K., Modise, B., Robinson, S., Simbanegavi, W., Van Seventer, D \& Anderson, L. (2020). Impact of Covid-19 on the South African economy: An initial analysis. SA-TIED Working Paper 111 | April 2020. WIDER / National Treasury: Pretoria. [Online] Available: https://satied.wider.unu.edu/sites/default/files/pdf/SA-TIED-WP-111.

Bai, Y., Yao, L., Wei, T., Tian, F., Jin, D.Y., Chen, L. \& Wang, M. (2020). Presumed Asymptomatic Carrier Transmission of COVID-19. Journal of American Medicine Association, 323(14), 1406-o7. [Online] Available: Doi:10.1001/jama.2020.2565

Caduff, C. (2020). What Went Wrong Corona and the World after the Full Stop? King's College London, Paper accepted for publication in Medical Anthropology Quarterly. Accepted 15 May 2020. [Online] Available: https://doi.org/10.1111/maq.12599.

Child, K. (2020). More than 40,0oo deaths predicted: behind SA's Covid-19 models. Business Live, 20 May, 1-3. [Online] Available: https://www.businesslive.co.za/fm/features/more-than-40ooo-deaths-predicted-behindsas-covid-19-models/ (May, 20, 2020).

Children's Act. (2005). “Act No. 38 of 2005”. Pretoria: Government Printer. 
Cirrincione, L., Plescia, F., Caterina Ledda, C., Rapisarda, V., Martorana, D., Moldovan, R.E., Theodoridou, K. \& Cannizzaro, E. (2020). COVID-19 Pandemic: Prevention and Protection Measures to Be Adopted at the Workplace. Sustainability, 12, 1-18. [Online] Available: Doi:10.339o/su12093603.

Cowan, K. (2020). South Africa's 14 Covid-19 hotspots - and the areas emerging as new hotspots. News24, 29 May, 16. [Online] Available: https://www.news24.com/news24/SouthAfrica/Investigations/sas-14-covid-19hotspots-and-the-areas-emerging-as-new-hotspots (May 29, 2020).

Daniels, L. (2020). Reopening of schools during Covid-19: How other countries have fared. New Politics, 20 May, 16. [Online] Available: https://www. iol.co.za/news/politics/reopening-of-schools-during-covid-19-howother-countries-have-fared-48212849/ (May 20, 2020).

Davis, R. (2020). Latest Covid-19 projections suggest SA cases could total three million. Daily Maverick, 12 June, 110. [Online] Available: https://www.dailymaverick.co.za/article/-latest-covid-19-projections-suggest-sacases-could-total-three-million/ (May 22, 2020).

Department of Basic Education. (2020). Basic Education Gazette for reopening of schools. Government Gazette, 659, May 29, No. 43372.

Department of Health. (2020a). Statement on the Cabinet meeting of 11 March 2020. Cape Town, 11 March 2020.

Department of Health. (202ob). Presentation to the National Command Council: Easing the Lockdown. Pretoria, 19 May 2020.

Department of Health. (2020c). Minister of Health Media Release: Update on COVID-19. Pretoria, 24 May 2020. Department of Health. (2020d). Minister of Health Media Release: Update on COVID-19. Pretoria, 29 May 2020. Department of Health. (2020e). Minister of Health Media Release: Update on COVID-19. Pretoria, 30 May 2020. Department of Health. (2020f). Minister of Health Media Release: Update on COVID-19. Pretoria, 31 May 2020.

European Centre for Disease Prevention and Control. (2020). COVID-19 Situation Update Worldwide. Europe, 27 May. [Online]Available:https://www.ecdc.europa.eu/en/geographical-distribution-2019-ncov-cases/ (May 27, 2020).

Evans, J. (2020). 98 teachers in Western Cape positive for Covid-19, as 16 schools close. News24, 11 June, 1-2. [Online]Available:https://www.news24.com/news24/southafrica/news/98-teachers-in-western-capepositive-for-covid-19-as-16-schools-close/ ( June 11, 2020).

Felman, A. (2020). What to know about pandemics? Medical News Today, 30 March, 1-10. [Online] Available: https://www.medicalnewstoday.com/articles/148945 1/ (March 30, 2020).

Fengu, M. (2020). Plan to reopen schools after lockdown takes shape, but some parents, teacher unions don't think it's a good idea. City Press, 18 April, 1-4. [Online] Available: https://www.news24.com/citypress/news/planto-reopen-schools-after-lockdown-takes-shape-but-some-parents-teacher-unions-dont-think-its-a-good-i... 1/1/ (April 18, 2020).

Fleming, L. (2020). Coronavirus: South Africa cases pass half million mark. BBC News, 2 August, 1-10. [Online] Available: https://www.bbc.com/news/world-africa-53625789/ (August 2, 2020).

Geach, C. (2020). Educators 'not coping with stress' as 19 school staff die of Covid-19 in Western. Argus News, 4 July, 1-8. [Online] Available: https://www.iol.co.za/weekend-argus/news/educators-not-coping-with-stress-as-19school-staff-die-of-covid-19-in-western-cape-50387182/ ( July 4, 2020).

Guo, Y.; Cao, Q.; Hong, Z.; Tan, Y.; Chen, S.; Jin, H.; Tan, K.; Wang, D. (2020). The origin, transmission and clinical therapies on coronavirus disease 2019 (COVID-19) outbreak - an update on the status. Military Medical Research, 7(1), 1-41. [Online] Available: Doi: 10.1186/s40779-020-00240-0.

Huang, C., Wang, Y., Li, X., Ren, L., Zhao, J., Hu, Y. (2020). Clinical features of patients infected with 2019 novel coronavirus in Wuhan, China. Lancet, 395, 497-506. [Online] Available: Doi: https//doi.org/10.1016/So140$6736(20) 30183-5$.

Hunter, Q. (2020). Grim Covid-19 projections for SA: 40 ooo deaths, 1 million infections and a dire shortage of ICU beds. News24, 19 May, 1-6. [Online]Available: https://www.news24.com/SouthAfrica/News/ (May 19, 2020)

Jacobs, K. (2020). Several children being treated for COVID-19 at Red Cross Hospital. Cape TownEtc, 4 June, 1-2. [Online] Available: https://www.capetownetc.com/news/several-children-being-treated-for-covid-19-at-redcross-hospital/ (June 4, 2020).

Jin, Y.H., Cai, L., Cheng, Z.S., Cheng, H., Deng, T., Fan, Y.P. (2020). A rapid advice guideline for the diagnosis and treatment of 2019 novel coronavirus (2019-nCoV) infected pneumonia (standard version). Military Medical Research, 7(4), 1-23. [Online] Available: Doi: https://doi.org/10.1186/s40779-020-0233-6.

Joint Media Statement. (2020). Joint Media Statement on the Consultations by the Minister of Basic Education with the Trade Unions on the Reopening of the Pre-schools and Schools. 12 May 2020.

Kanyinda, J., N., M. (2020). Coronavirus (COVID-19): A protocol for prevention and treatment. European Journal of Medical and Health Sciences, 2(3), 1-4. [Online] Available: Doi: 10.24018/ejmed.2020.2.3.340. 
Kavak, G. (2020). South Africa: 1,80o students infected by COVID-19 Provincial education minister says reopening of schools has not spiked new cases. Anadolu Agency, 15 June, 1-2. [Online] Available: https://www.aa.com.tr/en/africa/south-africa-1-8oo-students-infected-by-covid-19/1878145/ (June 15, 2020).

Kgosana, R. (2020). Cosas threatens to shut down schools in the Western Cape and Gauteng due to Covid-19. The Citizen, 15 June, 1-5. [Online] Available: https://citizen.co.za/news/covid-19/2302696/cosas-threatens-toshut-down-schools-in-the-western-cape-and-gauteng-due-to-covid-19/(June 15, 2020).

Khan, T.M. (2020). Preventive and Control Measures of COVID-19 Patients: A Review. Bangladesh Journal of Infectious Diseases, 7(1), 41-4. [Online] Available: https://doi.org/10.3329/bjid.v7io.4680o

Khumalo, K. (2020). 204 learners test positive for COVID-19 at an Eastern Cape School. Sunday World, 23 June, 1-4. [Online] Available: https://sundayworld.co.za/breaking-news/204-learners-test-positive-for-covid-19-at-aneastern-cape-school/(June 23, 2020).

King, S.J. (2020). You can't swap a teacher for home schooling, that's nonsense' - Jonathan Jansen. Cape Talk, 14 April, 1-4. [Online] Available: https://www.capetalk.co.za/ (April 14, 2020).

Magome, M. (2020). Concern over rapid rise in COVID-19 cases in South Africa. Medical Press, 21 July, 1-3. [Online] Available: https://www.wrbl.com/news/international/concern-over-rapid-rise-in-covid-19-cases-in-southafrica/(July 21, 2020).

Mahamba, C. (2020). Covid-19 shuts more Gauteng schools as pupils, teachers test positive. The Star News, 19 June, 1-7. [Online] Available: https://www.iol.co.za/the-star/news/covid-19-shuts-more-gauteng-schools-aspupils-teachers-test-positive-4960o864/(June 19, 2020).

Mahaye, N.E. (2020). The Impact of COVID-19 Pandemic on Education: Navigating Forward the Pedagogy of Blended Learning. ResearchGate, 1-24. [Online] Available: https://www.researchgate.net/publication/340899662

Makhubele, W. (2020). No teacher, learner infected with COVID-19 in Gauteng public schools since reopening: Lesufi. SABC News, 14 June, 1-3. [Online] Available: https://www.sabcnews.com/sabcnews/no-teacherlearner-infected-with-covid-19-in-gauteng-public-schools-since-reopening-lesufi/(June 14, 2020).

Masekela, R. \& A J Wessels, A.J. (2020). Controversies and challenges with COVID-19 in children: Why are they less susceptible and should they be at home rather than in school? African Journal of Thoracic Critical Care Medicine 2020; 26(3), 72-3. [Online] Available: https://doi. org/10.7196/AJTCCM.2020. v 26i3.114

McLaughlin, K. (2020). At least 5 teachers have died from COVID-19 since the school year began. Here are their stories. Insider, 15 September, 1-26. [Online] Available: https://www.insider.com/teachers-who-died-covid-19school-year-2020-9/(September 15, 2020).

Mlamla, S. (2020). 32 Schools in the Western Cape are affected by COVID-19 cases. Cape Argus, 29 May, 1-6. [Online] Available: https://www.iol.co.za/capeargus/news/ (May 29, 2020).

Molefe, R. (2020). Student body threatens Limpopo school shutdown amid Covid-19 concerns. News24, 25 June, 16. [Online]Available:https://www.news24.com/news24/southafrica/news/student-body-threatens-limpoposchool-shutdown-amid-covid-19-concerns/ (June 25, 2020).

Molele, C. (2020). Lesufi: 519 Teachers, 151 Learners Tested Positive For COVID-19 In Gauteng. Inside Education, 6 July, 1-5. [Online]Available: https://insideeducation.co.za/2020/o7/o6/lesufi-519-teachers-151-learners-testedpositive-for-covid-19-in-gauteng/(July 6, 2020).

Molele, C. \& Tefu, N. (2020). COVID-19 Crisis: DBE Announces Phased Re-Opening of Schools for Matrics and Grade 7 Learners. Inside Education, 29 April, 1-4. [Online] Available: https://insideeducation.co.za/ (April 29, 2020).

Motala, S \& Menon, K. (2020). In search of the 'new normal': Reflections on teaching and learning during Covid-19 in a South African university. Southern African Review of Education, 26(1),88-91. [Online] Available: https://www.researchgate.net/publication/343501284.

Mvumvu, Z. (2020). I can't guarantee that nobody will die Angie Motshekga on reopening schools. Sowetanlive, 19 May, 1-2. [Online] Available: https://www.sowetanlive.co.za/news/south-africa/ (May 19, 2020).

Mvumvu, Z. (2020). More than 1,500 schools hit by vandalism, theft during lockdown. Timeslive, 19 May, 1-3. [Online] Available: $\quad$ https://www.timeslive.co.za/news/south-africa/2020-05-19-more-than-150o-schools-hit-byvandalism-theft-during-lockdown/(May 19, 2020).

Nair, N. (2020). More KZN schools with Covid-19 cases suspend classes. Herald Live, 25 June, 1-4. [Online] Available: https://www.timeslive.co.za/news/south-africa/2020-o6-25-more-kzn-schools-with-covid-19-cases-suspendclasses/(June 26, 2020).

Ndebele, L. (2020). Zim Minister's bizarre coronavirus claim: It's to punish the West for sanctions. Timeslive, 16 March, 1-2. [Online] Available: https://www.timeslive.co.za/news/africa/ (March 16, 2020).

Njilo, N. (2020). Four confirmed Covid-19 cases in Gauteng schools - doctors, nurses to be deployed until next year. Timeslive, 29 May, 1-2. [Online] Available: https://www.timeslive.co.za/news/south-africa/ (May 29, 2020).

Nortier, C. (2020). Western Cape defends decision to reopen schools while minister apologises for postponement. Daily Maverick, 2 June, 1-11. [Online] Available: https://www.dailymaverick.co.za/article/ (June 02, 2020). 
Nyoni, K. (2020). Limpopo verifying number of schools currently closed due to COVID-19 infections. SABC News, 8 July, 1-3. [Online]Available:https://www.sabcnews.com/sabcnews/limpopo-verifying-number-of-schoolscurrently-closed-due-to-covid-19-infections/(July 8, 2020).

Parle, J. (2019). In a Time of Plague: Memories of the 'Spanish' Flu Epidemic of 1918 in South Africa. South African Medical Journal, 109 (5), 293-294. [Online] Available: https://www.researchgate.net/publication/333680193 (May 15, 2019).

Perper, R. (2020). France reports 70 new coronavirus cases in schools a week after reopening. Business Insider US, 19 May, 1-3. [Online] Available: https://www.businessinsider.co.za/(May 19, 2020).

Phagane, T. (2020). Parents anxious about children contracting COVID-19 in schools. SABC News, 3 June, 1-3. [Online] Available: https://www.sabcnews.com/sabcnews/parents-anxious-about-children-contractingcovid-19-in-schools/(June 3, 2020).

Pullella, P. (2020). Coronavirus: Don't celebrate victory over virus too soon, Pope warns Italians. Independent, 8 June, 1-5. [Online] Available: https://www.independent.co.uk/news/world/europe/ (June o8, 2020).

Rai, A. (2020). Kenya declares school year 'lost', classes back in 2021. Hindustantimes, 7 July, 1-2. [Online] Available: https://www.hindustantimes.com/world-news/ (July 07, 2020).

Rall, S.A. (2020). Children less likely to die from Covid-19, NICD report confirms. IOL, 1 July, 1-7. [Online] Available: https://www.iol.co.za/news/south-africa/children-less-likely-to-die-from-covid-19-nicd-report-confirms$50237212 /(J u l y ~ 1,2020)$.

Rall, S.A. (2020). 139 teachers, 37 pupils in KZN test positive for coronavirus. The Mercury, 29 June, 1-3. [Online] Available: https://www.iol.co.za/mercury/news/139-teachers-37-pupils-in-kzn-test-positive-for-coronavirus50114281/ (June 29, 2020).

Ramrathan, L. (2020). School curriculum in South Africa in the Covid-19 context: An opportunity for education for relevance. Springer, 1-10. [Online] Available: https://doi.org/10.1007/s11125-020-09490-1

Republic of South Africa. (2020a). Statement by President Cyril Ramaphosa on Measures to Combat COVID-19 Epidemic. Union Buildings, Tshwane, 15 March 2020.

Republic of South Africa. (2020b). Statement by President Cyril Ramaphosa on Escalation of Measures to Combat Covid-19 Epidemic. Union Buildings, Tshwane, 23 March 2020.

Republic of South Africa. (1996a). The Constitution of South Africa Act No. 108 of 1996. Pretoria: Government Printer. Republic of South Africa. (1996b). South African Schools Act No. 84 of 1996. Pretoria: Government Printer.

Schleicher, A. (2020). The impact of COVID-19 on education: insights from Education at a Glance 2020. OECD, Paris, 4 November 2020. [Online] Available: https://www.oecd.org/education/the-impact-of-covid-19-oneducation-insights-education-at-a-glance-2020. /(November 4, 2020).

Singh, O. (2020). Grade R girl tests positive: Richards Bay school in lockdown. Timeslive, 16 March, 1-2. [Online] Available: https://www.timeslive.co.za/ (March 16, 2020).

Shaban, A. R. A. (2020). Coronavirus in Africa: 119,454 cases; 3,592 deaths; 48,607 recoveries. Africanews, 27 May, 16. [Online] Available: https://www.africanews.com/ (May 27, 2020).

Shereen, M.A., Khan, S., Kazmi, A., Bashir, N., \& Siddique, R. (2020). COVID-19 infection: Origin, transmission, and characteristics of human coronaviruses. Journal of Advanced Research, 24, 91-98. [Online] Available: https://doi.org/10.1016/j-jare.2020.03.005.

South African Democratic Teachers' Union. (2020). SADTU Media Statement on the State of Readiness to open Schools. 8 May 2020.

South African Democratic Teachers' Union, Limpopo Province. (2020). SADTU Limpopo Province Media Statement on the Re-Opening of Schools. 23 May 2020.

Spaull, N. \& Van der Berg, S. (2020). Counting the Cost: COVID-19 school closures in South Africa E its impacts on children. Research on Socioeconomic Policy (RESEP). Stellenbosch University. Stellenbosch. [Online] Available: Doi: https://doi.org/10.4102/sajce.v1oi1.924.

Tornali, C., Vecchio, FAG. \& Vecchio, I. (2020). Spanish Flu and Covid-19: Historical Correlations and Bioethical Implications. Journal of Clinical Research E Bioethics, 11(3), 1-4. [Online] Available: Doi: 10.35248/21559627.20.11.352.

Tsoucalas, G., Kousoulis, A. \& Sgantzos, M. (2016). The 1918 Spanish Flu Pandemic, the Origins of the H1N1-virus Strain, a Glance in History. European Journal of Clinical and Biomedical Sciences, 2(4), 23-8. [Online] Available: Doi: 10.11648/j.ejcbs.20160204.1.

Tswanya, Y. (2020). 379 pupils test positive for Covid-19 in Western Cape. Cape Times, 22 July, 1-7. [Online] Available: https://www.iol.co.za/capetimes/news/379-pupils-test-positive-for-covid-19-in-western-cape67863c91-oabe-4bb1-97a4-8d932cdaoe99/ (July 22, 2020).

UNESCO. (2020). From Sub-regional to a Continental Response Strategy in Support of more Resilient and Responsive Education Systems in Africa COVID-19 (C-19). April-June 2020. 
UNICEF. (2020a). Coronavirus disease (COVID-19) information centre. The latest COVID-19 news and resources, as well as tips to protect you and your family. 04 June 2020. [Online] Available: https://www.unicef.org/coronavirus/covid19/(June 04, 2020).

UNICEF. (2020b). South Africa COVID-19 Situation Report No. 7 01-31 August 2020, o1 August to 31 August 2020.

United Nation General Assembly. (1989). Convention on the Rights of the Child, 20 November 1989. United Nations, Treaty Series, 1577,3.

Wang J., Tang, K., Feng, K. \& Weifeng, L. (2020). High Temperature and High Humidity Reduce the Transmission of COVID-19. Research Gate, 1-27. [Online]Available: https://www.researchgate.net/publication/339873481/ (April 03, 2020)

Wiysonge, C.S. (2020). South Africa's War on COVID-19. Think Global Health, 20 April, 1-5. [Online] Available: https://www.thinkglobalhealth.org/article/south-africas-war-covid-19/ (April 20, 20202).

Western Cape Education Department (WCED). (2020). Indemnity forms and management of COVID-19 in schools. Pretoria: Government Printer. [Online] Available: https://wcedonline.westerncape.gov.za/news/indemnityforms-and-management-covid-19-cases-schools.

World Health Organisation. (2020). African countries move from COVID-19 readiness to response as many confirmed cases. Coronavirus (COVID-19) Regional Office for Africa, 27 May, 1-2. [Online] Available: https://www.afro.who.int/health-topics/coronavirus-covid-19 (May 27, 2020).

Xinhua. (2020). Egypt reopens schools for 23 million students amid anti-coronavirus measures. Africa Live, 17 October, 1-3. [Online] Available: https://africa.cgtn.com/2020/10/17/egypt-reopens-schools-for-23-millionstudents-amid-anti-coronavirus-measures/ (October 17, 2020).

Zulu, S. (2020). 3 more Gauteng Schools closed following heightened Covid-19 concerns. Eyewitness News, 22 June, 1-6. [Online] Available: https://www.msn.com/en-za/news/national/3-more-gauteng-schools-closedfollowing-heightened-covid-19-concerns/ar-BB15QmRG/(June 22, 2020). 